\title{
Growth Effect of Oncorhychus masou by Recombinant Myostatin Prodomain Proteins Derived from Fish
}

Jeong Hwan Kim', Sang Beum Lee', Mi Jin Cho', Ji Young Ahn², Suk Keun Lee', Sung-Youl Hong', Ki Baik Seong ${ }^{5}$ and Hyung-Joo Jin ${ }^{1}$ *

\author{
${ }^{1}$ Department of Marine Molecular Biotechnology, Gangnung-Wonju National University, Gangneung 210-702, Korea \\ ${ }^{2}$ Marine application Biotechnology, Marine Bioindustry cooperation, Gangnung-Wonju National University, Gangneung 210-702, Korea \\ ${ }^{3}$ Department of pathology, College of dentistry, Gangnung-Wonju National University, Gangneung 210-702, Korea \\ ${ }^{4}$ Gyeonggi Province Freshwater Fisheries Research Institute, Gyeonggi-do, 476-841, Korea \\ ${ }^{5}$ Inland Aquaculture Research Center, NFRDI, Korea
}

Received May 12, 2011 /Revised August 3, 2011 /Accepted August 4, 2011

\begin{abstract}
Myostatin (MSTN) belongs to the transforming growth factor- $\beta$ superfamily or growth and differentiation factor 8 (GDF-8), and functions as a negative regulator of skeletal muscle development and growth. Previous studies in mammals have suggested that myostatin knock-out increased muscle mass and decreased fat content compared to those of the wide type. Recently, several studies on myostatin have beenconducted on the block myostatin signal pathway with myostatin antagonists and the MSTN regulation with RNAi to control myostatin function. This study was performed to analyze growth and muscle alteration of Oncorhychus masou by treatment with recombinant myostatin prodomains derived from fish. We designed myostatin prodomains derived from $P$. olivaceus (pMALc2x-poMSTNpro) and $S$. schlegeli (pMALc2x-sMSTNpro) in a pMALc2x expression vector, and then purified the recombinant proteins using affinity chromatography. The purified recombinant proteins were treated in $O$. masou through an immersion method. Recombinant protein treated groups did not show a significant difference in weight, protein, or lipid composition compared to the control. However, there was a difference in the average number and area for histological analyses in the muscle fiber. At twelve and twenty-two weeks from the initial treatment, there were differences in average fiber number and area between the $0.05 \mathrm{mg} / \mathrm{l}$ treated-group and the control, but the numbers were similar to those of the control during the same time period. At twelve weeks, however, $0.2 \mathrm{mg} / 1$ treated-group had an increase in average fiber number and decrease in average fiber area compared to the control. At twenty-two weeks, the pMALc2x-sMSTNpro $0.2 \mathrm{mg} / 1$ treated-group was induced and showed a decrease in average fiber number and increase in average fiber area. The results between twelve and twenty-two weeks showed that the fiber numbers had decreased, whereas average fiber area had increased due to sMSTNpro. It is understood that the sMSTNpro induced only hyperplasia at twelve weeks, after which it induced hypertrophy. Recombinant myostatin prodomains derived from fish may induce hyperplasia and hypertrophy in $O$. masou depending upon the time that has elapsed.
\end{abstract}

Key words : Myostatin, prodomain, Oncorhychus masou, Paralichthys olicaveus, Sebasted schlegeli

\section{서 론}

형질 변환 성장인자(transforming and growth factor $\beta$, TGF-3)의 superfamily 중 하나인 myostatin은 1997년 발견되 었으며 성장과 분화를 조절하는 성장분화인자(growth and differentiation factor-8, GDF-8)로 알려져 있다[19]. Myostatin 은 주로 골격근의 근육 성장을 억제하는 인자로서 근육에서 특이적으로 많이 발현되는 특징을 가지고 있다[19]. Myostatin 기능이 소실된 소와 생쥐 같은 포유동물에서 과도한 근육발달

*Corresponding author

Tel: +82-33-640-2349, Fax: +82-33-640-2340

E-mail : hj-jin@gwnu.ac.kr
을 유도한다고 보고되어 있으며 대표적인 예로 Belgian blue 와 Piedomontease가 있다. 이 개체들은 myostatin 유전자의 돌연변이로 인해 정상적인 소보다 골격근의 성장이 발달하여 체중이 2 3배 증가한다고 알려져 있다 $[8,11,19]$. 또한 myostatin knock-out 쥐의 경우 근섬유 크기와 수의 증가로 정상 개체보다 골격근의 양이 증가되었고, 지방함량이 감소되었다 고 보고되었다[18].

Myostatin 유전자 연구는 포유류뿐만 아니라 어류에서도 다양하게 연구가 진행되고 있으며 어류 myostatin 기능 또한 포유류와 동일한 것으로 추정되고 종간 유전자의 보존성이 높은 것으로 알려져 있다[2,7,25,36]. 어류 myostatin은 포유 류와 달리 2가지의 isoform이 존재하며, 주로 골격근에서 발 
현하는 포유류와는 달리 골격근을 포함한 거의 모든 조직에 서 발현되는 것으로 알려져 있다[24,27,29]. 지금까지 밝혀진 myostatin 신호 전달은 myostatin 유전자로부터 번역을 통해 signal peptide, prodomain, mature로 발현되며 단백질 분해 효소들에 의해 prodomain과 mature 경계 RXRR 부분이 절 단되고, prodomain과 mature는 비공유 결합을 통해 세포 밖 으로 분비된다. 이후 prodomain을 절단하는 효소에 의해 비 공유 결합이 끊어지게 되고 활성 myostatin은 activin type II 수용체에 결합을 함으로서 신호를 전달하게 된다. 수용체 와 결합한 myostatin은 smad2/3를 인산화 시키고 samd 4 와 결합하여 목적 유전자의 전사를 조절하게 된다. 이러한 myostatin 신호전달의 억제인자로는 follistatin [22], follistatin related gene (FLRG) [9], growth and differentiation factor-associated serum protein-1 (GASP-1) [10], human small glutamine-rich tetratricopeptide repeat-containing protein (hSGT) [35], Titin-cap (T-cap) [23], myostatin prodomain [16] 등이 있으며 이러한 인자들은 활성 myostatin이 activin type II 수용체와 결합을 하지 못하도록 하여 신호전달을 억 제하는 것으로 알려져 있다[9,10,22,23,35]. 최근 myostatin prodomain을 이용한 활성 myostatin 억제에 관한 연구에 의 하면 무지개 송어 치어에 넙치유래 재조합 myostatin prodomain을 처리한 결과 최대 약 $42 \%$ 무게 증가를 나타내었다 [15]. 이러한 결과를 바탕으로 본 연구는 시마연어를 대상으 로 myostatin 신호전달을 억제하는 어류 유래 myostatin prodomain을 생산하여 시마연어에 처리한 후 체중 변화, 근 육 구성성분 분석과 근 조직의 조직학적 변화를 통해 myostatin prodomain이 시마연어 성장 및 근육 형성에 어떠한 역할을 하는지에 대해 알아보고자 하였다.

\section{재료 및 방법}

\section{어류 유래 재조합 myostatin prodomain 발현 및 정제}

본 연구에 사용된 넙치와 조피볼락 유래 myostatin prodomain (pMALc2x-poMSTNpro, pMALc2x-sMSTNpro)은 Lee 등(2010; 2011)에 의해 구축된 균주를 사용하였다. 발현 균주로 부터 재조합 단백질을 얻기 위해 고체배지에서 배양한 단일 콜로니를 $0.2 \%$ glucose가 포함된 LB (Luria-Bertani, $1.2 \%$ tryptone, $0.6 \%$ yeast extract and $0.8 \% \mathrm{NaCl}$ ) 배지에 접종하였 다. 배양액은 $37^{\circ} \mathrm{C}$ 에서 $\mathrm{OD} 600$ 값이 $0.4 \sim 0.6$ 이 될 때까지 배양 한 뒤 $0.2 \mathrm{mM} \mathrm{IPTG를} \mathrm{처리하고} \mathrm{2시간} \mathrm{동안} \mathrm{단백질} \mathrm{발현을}$ 유도하였다. 발현 유도된 대장균은 $13,000 \mathrm{rpm}$ 으로 10 분간 $4^{\circ} \mathrm{C}$ 에서 원심분리를 실시하여 상등 액만 회수하였고, 회수된 대장균은 초음파 분쇄기를 이용하여 파쇄한 후 원심분리 하여 상등 액만 amylose resin (NEB, USA)을 이용한 affinity chromatography를 통해 재조합 단백질을 정제하였다. 정제된 단 백질은 SDS-PAGE와 Bradford assay (Bio-Rad, USA)를 통해
정량 분석하여 동결건조 한 뒤 실험 전까지 $-20^{\circ} \mathrm{C}$ 에서 보관하 였다.

\section{재조합 myostatin prodomain 단백질 침지}

실험에 사용한 시마연어는 무게 $1 \mathrm{~g}$ 내외의 개체를 선별하 였다. 침지 실험방법은 Lee 등(2010)의 방법에 따라 수행하였 으며 사용한 재조합 myostatin prodomain (pMALc2xpoMSTNpro, pMALc2x-sMSTNpro) 농도는 각각 $0.05 \mathrm{mg} / 1$ 와 $0.2 \mathrm{mg} / 1$ 이며 각 실험 군은 한 수조당 60 마리의 시마연어를 수용하여 3 회 반복 구 실험을 하였다. 재조합 단백질의 침지는 매주 2회, 4 주간 처리하였고 매주 모든 그룹의 개체 무게를 측정하였다. 4 주 이후에는 12 주, 22 주에 모든 그룹의 개체 무 게를 측정하였다. 대조 군은 아무것도 처리하지 않은 그룹과 Tris buffer $(20 \mathrm{mM}$ Tris-HCl, pH 8.0, $200 \mathrm{mM} \mathrm{NaCl}, 1 \mathrm{mM}$ $\mathrm{EDTA})$ 를 처리한 그룹을 사용하였다.

\section{근육의 단백질/지질 함량 및 조직 분석}

재조합 myostatin prodomain 단백질을 4 주 동안 침지 한 후, 12 주와 22 주에 각각 근육조직을 채집하여 근육 단백질과 지질 함량, 조직학적 분석을 하였다. 단백질과 지질 함량 분석 은 $\mathrm{AOAC}$ 방법[3]에 의해 어류의 뽸와 피부를 제외한 순수 근육 부위를 가지고 수행하였다. 조직분석은 근육조직을 파라 핀 고정을 통해 $10 \mu \mathrm{m}$ 박편을 제작하여 hematoxylin/eosin으 로 염색 한 뒤 Image J 프로그램(http://rsbweb.nih.gov/ij)을 이용한 근섬유의 수, 면적 그리고 지름을 측정하였다.

\section{통계처리}

통계처리는 SPSS 18.0 프로그램을 이용하여 One-way ANOVA test를 실시하여 Duncan 검정을 통해 12 주와 22주 에 개체 무게, 단백질과 지질 함량, 근섬유의 수와 평균 면적 을 대조 군과 재조합 myostatin prodomain 실험구간의 유의 성을 분석하였다[4]. 모든 통계적 유의 수준은 $p<0.05$ 에서 채 택하였다.

\section{결 과}

\section{넙치 유래 재조합 myostatin prodomain}

넙치 유래 재조합 myostatin prodomain (pMALc2xpoMSTNpro) 처리 후 매주 무게를 측정한 결과 실험 군과 대 조군 사이에는 유의성이 나타나지 않았지만 $0.05 \mathrm{mg} / 1$ 로 처리 한 그룹에서 12 주, 22 주 각각 대조 군에 비해 약 $6 \%, 7 \%$ 증가하 였고 $0.2 \mathrm{mg} / 1$ 로 처리한 그룹에서는 12 주에는 $3 \%$ 감소하고 22 주에는 $1 \%$ 증가하는 경향이 나타났다(Fig. 1).

근육 단백질 함량은 $0.05 \mathrm{mg} / 1$ 침지한 그룹에서 12 주, 22 주 각각 대조 군에 비해 $\mathrm{g}$ 당 $3 \%, 5 \%$ 증가하였으며, 0.2 $\mathrm{mg} / \mathrm{l}$ 침지한 그룹에서는 12 주에 대조 군에 비해 $3 \%$ 증가하 
(A)

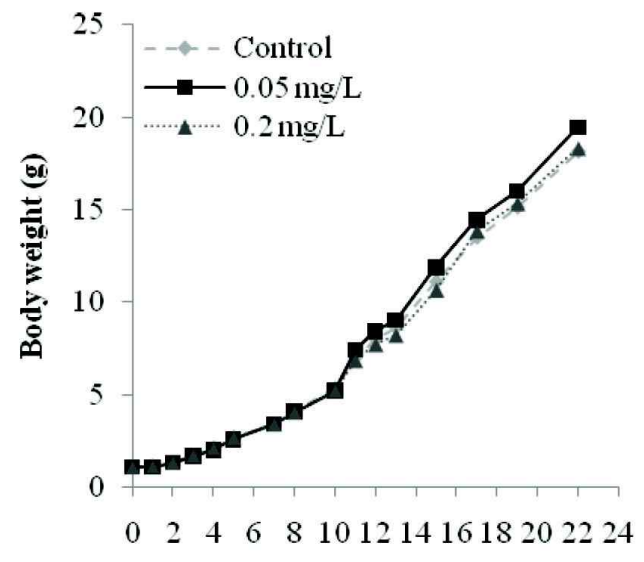

Weeks
(B)

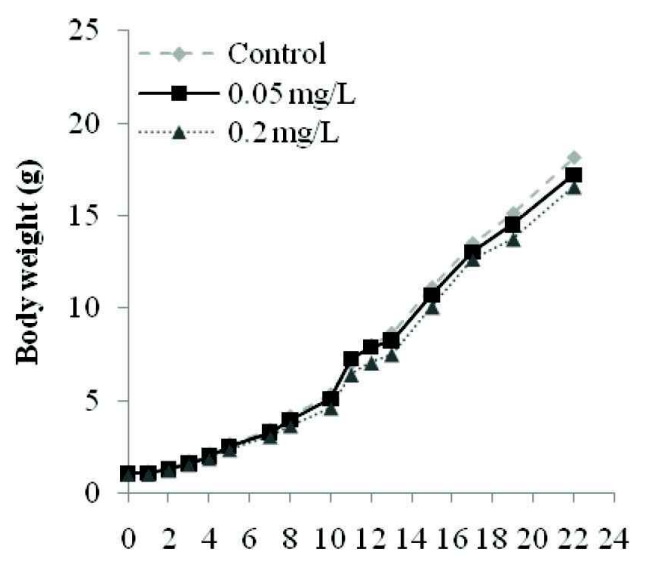

Weeks

Fig. 1. Body weight variation of $O$.masou treated with pMALc2x-poMSTNpro and pMALc2x-sMSTNpro. (A) pMALc2x-poMSTNpro treated group, (B) pMALc2x-sMSTNpro treated group

Table 1. Biochemical analysis of young $O$. mason treated with pMALc2x-poMSTNpro and pMALc2x-sMSTNpro

\begin{tabular}{|c|c|c|c|c|c|c|}
\hline \multirow{2}{*}{12 weeks } & \multirow{2}{*}{ Control } & \multirow{2}{*}{ Tris buffer } & \multicolumn{2}{|c|}{ pMALc2x-poMSTNpro } & \multicolumn{2}{|c|}{ pMALc2x-sMSTNpro } \\
\hline & & & $0.05 \mathrm{mg} / 1$ & $0.2 \mathrm{mg} / \mathrm{l}$ & $0.05 \mathrm{mg} / 1$ & $0.2 \mathrm{mg} / \mathrm{l}$ \\
\hline Muscle protein, $\%$ & $81.48 \pm 0.60^{\mathrm{ns}}$ & $83.19 \pm 0.56$ & $84.68 \pm 0.43$ & $84.71 \pm 0.29$ & $84.40 \pm 0.56$ & $86.49 \pm 0.57$ \\
\hline Muscle lipid, \% & $12.54 \pm 0.46^{\mathrm{ns}}$ & $11.46 \pm 0.65$ & $10.05 \pm 0.88$ & $10.33 \pm 0.51$ & $10.56 \pm 0.50$ & $8.28 \pm 0.32$ \\
\hline Weight, $\mathrm{g}$ & $7.97 \pm 0.13^{\mathrm{ns}}$ & $7.96 \pm 0.22$ & $8.44 \pm 0.27$ & $7.71 \pm 0.35$ & $7.90 \pm 0.27$ & $7.09 \pm 0.16$ \\
\hline${ }^{1)}$ Muscle fiber count, $\mathrm{mm}^{2}$ & $65.00 \pm 4.51^{\mathrm{a}}$ & $70.67 \pm 4.48$ & $60.33 \pm 1.20^{\mathrm{a}}$ & $109.33 \pm 1.20^{b}$ & $75.33 \pm 2.96^{\mathrm{a}}$ & $125.00 \pm 11.53^{b}$ \\
\hline Total area, $\mathrm{mm}^{2}$ & $21275.86 \pm 147.99$ & $21274.12 \pm 278.95$ & $21093.01 \pm 236.68$ & $17623.95 \pm 351.46$ & $23127.08 \pm 834.16$ & $19462.53 \pm 374.76$ \\
\hline Average area, $\mathrm{mm}^{2}$ & $330.04 \pm 19.68^{a b}$ & $303.95 \pm 23.21$ & $349.89 \pm 7.92^{\mathrm{a}}$ & $161.28 \pm 4.56^{\mathrm{c}}$ & $307.20 \pm 6.75^{b}$ & $158.63 \pm 16.00^{\mathrm{c}}$ \\
\hline \multirow{2}{*}{22 weeks } & Control & Tris buffer & \multicolumn{2}{|c|}{ pMALc2x-poMSTNpro } & \multicolumn{2}{|c|}{ pMALc2x-sMSTNpro } \\
\hline & $0 \mathrm{mg} / \mathrm{l}$ & $600 \mathrm{ul} / 1$ & $0.05 \mathrm{mg} / 1$ & $0.2 \mathrm{mg} / \mathrm{l}$ & $0.05 \mathrm{mg} / 1$ & $0.2 \mathrm{mg} / 1$ \\
\hline Crude protein, $\%$ & $81.67 \pm 0.011^{\mathrm{ns}}$ & $84.34 \pm 0.53$ & $86.74 \pm 0.27$ & $80.32 \pm 0.19$ & $84.29 \pm 0.89$ & $79.62 \pm 0.19$ \\
\hline Crude lipid, \% & $12.31 \pm 2.72^{\mathrm{ns}}$ & $11.08 \pm 0.63$ & $10.43 \pm 0.19$ & $14.31 \pm 0.12$ & $10.94 \pm 1.07$ & $15.08 \pm 0.28$ \\
\hline Weight, g & $18.13 \pm 1.17^{\mathrm{ns}}$ & $18.40 \pm 0.72$ & $19.47 \pm 2.13$ & $18.33 \pm 0.10$ & $17.20 \pm 0.69$ & $16.57 \pm 0.80$ \\
\hline Muscle fiber count, $\mathrm{mm}^{2}$ & $108.67 \pm 4.81^{\mathrm{a}}$ & $99.33 \pm 6.98$ & $101.67 \pm 5.61^{\mathrm{a}}$ & $88.67 \pm 2.96^{a b}$ & $80.33 \pm 9.06^{b}$ & $87.67 \pm 7.22^{a b}$ \\
\hline Total area, $\mathrm{mm}^{2}$ & $21618.75 \pm 582.10$ & $22465.48 \pm 308.49$ & $15933.00 \pm 379.61$ & $16507.28 \pm 351.69$ & $21544.33 \pm 1261.02$ & $20529.24 \pm 403.16$ \\
\hline Average area, $\mathrm{mm}^{2}$ & $199.33 \pm 5.49^{\mathrm{ab}}$ & $228.50 \pm 16.73$ & $157.55 \pm 8.33^{b}$ & $186.36 \pm 2.91$ ab & $275.95 \pm 36.65^{\mathrm{c}}$ & $237.45 \pm 20.11^{\mathrm{ac}}$ \\
\hline
\end{tabular}

Values ase mean \pm SE of three replications. Different letters are significantly difference $(p<0.05)$.

${ }^{1)}$ Muscle fiber count and average area measured in the epaxial muscles adjacent to vertebral column

${ }^{\text {ns }}$ Not significant $(p>0.05)$

였다. 지방함량의 경우 단백질 함량과는 대조적으로 0.05 $\mathrm{mg} / 1$ 로 처리한 그룹에서 12 주, 22주 모두 대조 군에 비해 $2 \%$ 감소하였고, $0.2 \mathrm{mg} / 1$ 로 처리한 그룹에서는 12 주에서 대 조 군에 비해 $2 \%$ 감소하고 22 주에서는 $2 \%$ 증가를 확인할 수 있었다(Table 1).

근육조직의 조직학적 분석 결과, 12 주후 $0.2 \mathrm{mg} / 1$ 침지한 그룹에서 대조 군에 비해 근섬유의 수가 $68 \%$ 증가하고 근섬유 의 평균 면적이 $51 \%$ 감소하였다. 이와는 반대로 $0.05 \mathrm{mg} / 1$ 침지한 그룹에서는 근섬유의 수가 $7 \%$ 감소하고 근섬유의 평
균 면적이 $6 \%$ 증가하였다. 한편 22주 후 개체에서는 $0.2 \mathrm{mg} / 1$ 침지한 그룹에서 근섬유의 수가 $18 \%$ 감소하고 근섬유의 평균 면적 역시 7\% 감소하였다. $0.05 \mathrm{mg} / \mathrm{l}$ 침지한 그룹에서도 근섬 유 수 및 근섬유 평균 면적이 각각 $6 \%, 21 \%$ 감소하였다. 12 주 와 22 주 사이의 변화 양상을 보면 $0.05 \mathrm{mg} / 1$ 침지한 그룹이 근섬유 수 증가, 근섬유 면적 감소와 같이 대조 군과 유사한 형태로 성장하였고 $0.2 \mathrm{mg} / 1$ 침지한 그룹은 대조 군과 반대 경향으로 성장하였다(Table 1, Fig. 2). 근 섬유의 지름을 측정 한 결과 12 주와 22 주 후 대조 군에 비해 $0.05 \mathrm{mg} / 1$ 침지한 


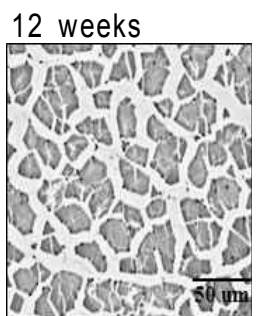

(A)

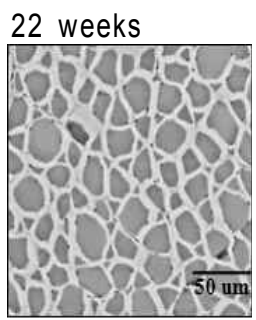

(A)

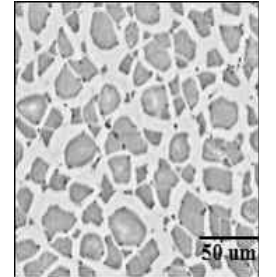

(B)

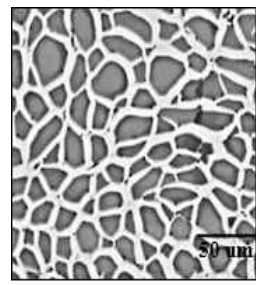

(B)

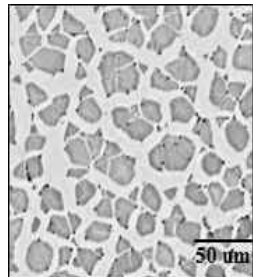

(C)

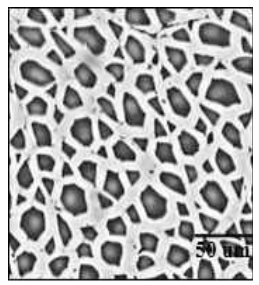

(C)

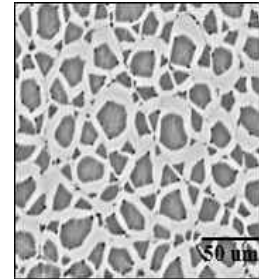

(D)

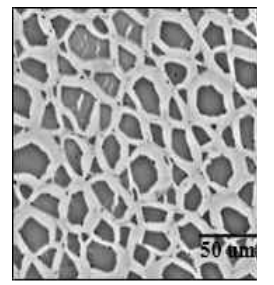

(D)

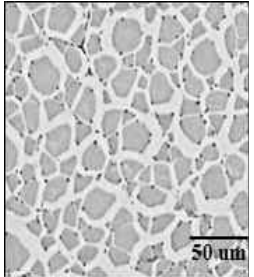

(E)

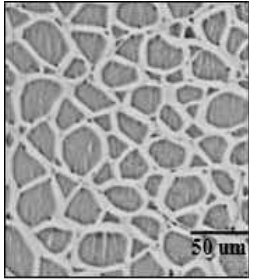

(E)

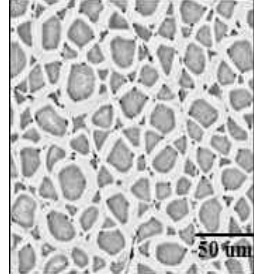

(F)

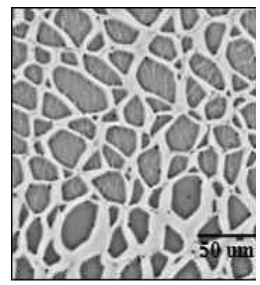

(F)

Fig. 2. Histology analysis of muscle fiber of $O$. masou. (A) Control group, (B) Buffer group, (C) $0.05 \mathrm{mg} / 1$ of pMALc2x-poMSTNpro, (D) $0.2 \mathrm{mg} / 1$ of pMALc2x-poMSTNpro, (E) $0.05 \mathrm{mg} / 1$ of pMALc2x-sMSTNpro, (F) $0.2 \mathrm{mg} / 1$ of pMALc2x-sMSTNpro

그룹에서 작은 크기의 근섬유가 많이 분포하는 것을 확인 할 수 있었고, $0.2 \mathrm{mg} / 1$ 침지한 그룹에서는 12 주에 작은 크기의 근섬유가 많이 분포하다가 22주가 되어 큰 근섬유의 분포가 많아진 것을 확인할 수 있었다(Fig. 3).

\section{조피볼락 유래 재조합 myostatin prodomain}

조피볼락 유래 재조합 myostatin prodomain (pMALc2xsMSTNpro) 단백질을 침지한 그룹에서는 pMALc2xpoMSTNpro 단백질을 침지한 그룹과 마찬가지로 유의성이 나타날 정도의 무게차이는 보이지 않았지만 단백질 처리 농도 에 관계없이 대조 군에 비해 무게가 최대 $11 \%$ 줄어드는 경향 을 나타내었다(Fig. 1).

근육 단백질과 지질 함량은 pMALc2x-poMSTNpro 단백질 을 침지한 결과와 유사하게 나타났다. 근육 단백질 함량은 $0.05 \mathrm{mg} / \mathrm{l}$ 침지한 그룹에서 12 와 22주 후, 모두 대조 군에 비해 $3 \%$ 증가하였고 $0.2 \mathrm{mg} / 1$ 침지한 그룹에서는 12 주에서 $5 \%$ 증 가, 22 주에는 $2 \%$ 감소하였다. 지방함량의 경우 $0.05 \mathrm{mg} / 1$ 침지 한 그룹에서 12 주와 22 주 후에 각각 대조 군에 비해 $2 \%, 1 \%$ 감소하였고 $0.2 \mathrm{mg} / 1$ 침지한 그룹에서 12 주에 $4 \%$ 감소, 22 주 에 3\% 증가를 나타내었다(Table 1).

근육 조직분석 결과 근섬유 수와 근섬유 평균 면적이 pMALc2x-poMSTNpro 단백질을 $0.2 \mathrm{mg} / 1$ 침지한 그륩과 유 사하게 나타났으며, 재조합 myostatin prodomain 단백질 농 도에 의존적인 경향을 나타내었다. $0.05 \mathrm{mg} / 1$ 와 $0.2 \mathrm{mg} / 1$ 침지 한 그룹에서는 근섬유 수가 각각 $16 \%, 92 \%$ 가 증가하였고 근섬 유 평균 면적은 $7 \%, 52 \%$ 감소하였다. 한편 22주에는 근섬유의 수가 $26 \%, 19 \%$ 감소, 근섬유의 평균 면적은 $38 \%, 19 \%$ 증가하
였다. 12 주와 22 주 사이의 경향은 pMALc2x-poMSTNpro 단 백질을 침지한 그룹과 마찬가지로 $0.05 \mathrm{mg} / 1$ 침지한 그룹에서 근섬유 수는 증가하고 평균 면적이 감소하는 대조 군과 같은 경향의 성장을 나타냈고 $0.2 \mathrm{mg} / 1$ 침지한 그룹에서는 대조 군과는 반대로 근섬유 수는 감소하고 평균 면적은 증가하는 성장을 나타냈다(Table 1, Fig. 2). 근섬유 지름을 측정한 결과 는 12 주에 $0.05 \mathrm{mg} / \mathrm{l}, 0.2 \mathrm{mg} / 1$ 침지한 그룹 모두 대조 군에 비해 작은 크기의 근섬유가 많이 분포하는 경향을 나타내었고 22주에는 대조 군에 비해 모두 크기가 큰 근섬유들이 많이 분포하는 경향을 나타내었다(Fig. 3).

\section{고 찰}

개체 성장을 위한 근육발달은 근섬유의 hypertrophy와 hyperplasia에 의해서 이루어진다[11]. 근섬유의 hypertrophy와 hyperplasia는 myostatin 신호전달경로와 mTOR 신호전달경로 등으로 유도된다[5,36]. Myostatin 신호전달경 로는 myostatin을 리간드로 하여 activin type $\Pi$ receptor를 통해 Smad 전사인자들의 신호전달이 최종적으로 myostatin 유전자 과발현이 일어난다. 그 결과 근육 성장 억제가 일어 나게 되며, myostatin 활성을 억제하게 되면 Smad 전사 인 자 등의 신호가 차단되면서 최종적으로 myostatin 유전자가 발현되지 않아 근섬유의 hypertrophy 및 hyperplasia가 일 어나면서 근육성장을 촉진한다. $\mathrm{mTOR}$ 신호전달경로는 인 슐린 유사 성장인자(insulin like growth factor, IGF)를 리간 드로 하여 IGF-I receptor에 결합을 하게 되고 PI3K 및 Akt 전사인자들의 인산화를 통해서 $\mathrm{mTOR}$ 신호전달경로가 활성 
(A)

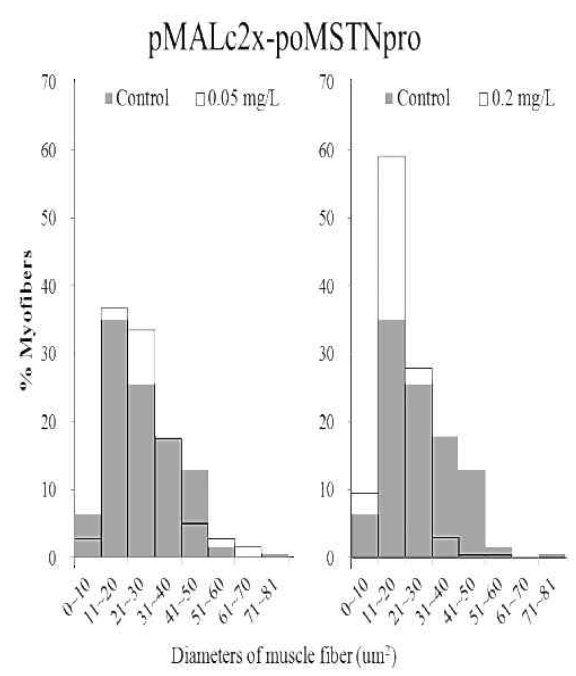

(B)

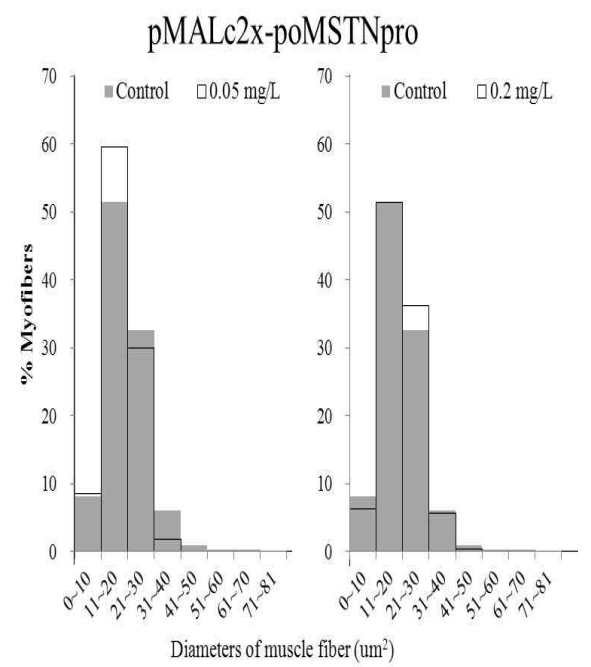

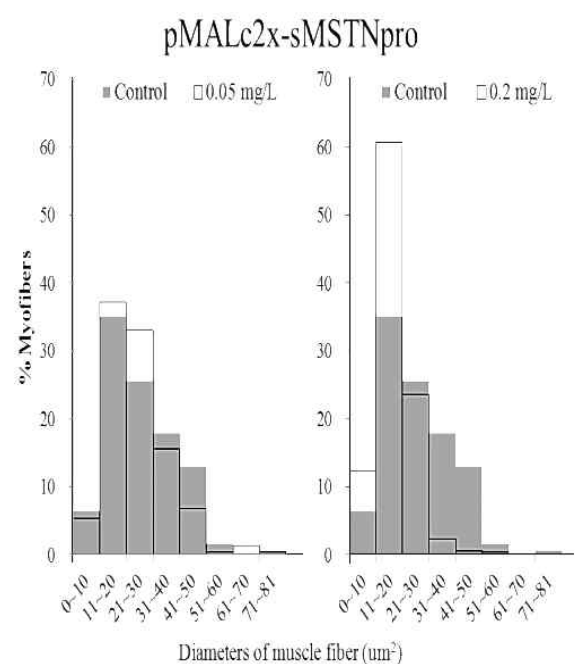

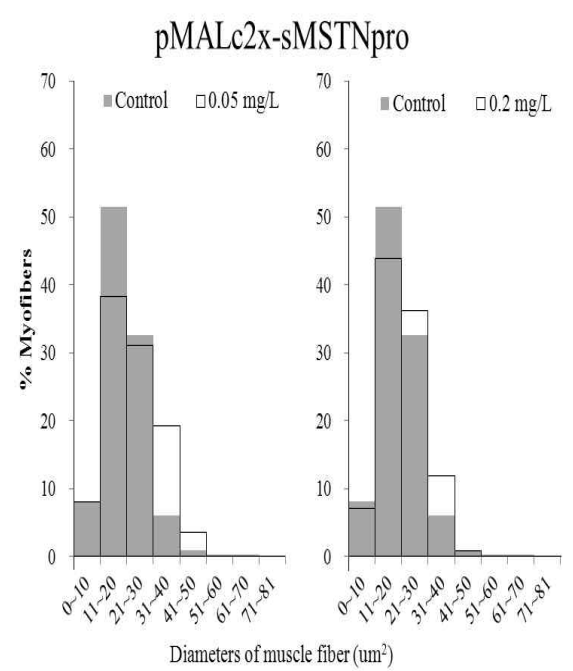

Fig. 3. The diameter of muscle fiber of control group and recombinant proteins (pMALc2x-poMSTNpro and pMALc2x-sMSTNpro) treated groups. (A) After 12 wk, (B) After 22 wk

화 된다. 활성화 된 $\mathrm{mTOR}$ 신호전달경로는 최종적으로 단 백질 합성을 촉진하여 근섬유의 hypertrophy를 유도하고, 특이적으로 S6 kinase 1 (S6K1)의 활성화는 glycogen synthase kinase 3 (GSK3)를 억제하면서 세포의 증식을 자극하 여 hyperplasia를 유도한다[33].

포유류 근육발달은 발생초기에 근섬유의 hyperplasia가 일 어나고 hypertrophy를 통해서 성장을 하는 것으로 알려져 있 는 반면 어류 근육발달은 발생초기뿐만 아니라 성장을 하는 기간 내내 근섬유의 hyperplasia와 hypertrophy가 복합적으 로 작용 함으로서 성장하는 것으로 알려져 있다[12,28]. 포유류 및 어류는 근섬유 수를 증가시키는 hyperplasia을 유도한 후, 근 섬유가 커지는 hypertrophy를 통해 개체의 근육이 발달한 다. 포유류를 대상으로 한 연구에서 myostatin 유전자를 knockout 시킨 쥐로부터 근육 양이 증가하는 현상을 확인하였 고, 조직분석 결과 근섬유의 hypertrophy와 hyperplasia가 복
합적으로 나타났다[18]. Myostatin prodomain의 과발현을 통 한 유전자조작 쥐에서도 조직분석을 통해 근섬유의 hyperplasia와 hypertrophy가 동시에 나타닜으며 결과적으로 쥐의 무게가 증가되었다[37]. 어류에서는 제프라피쉬의 myostatin 유전자 발현을 RNAi 기법을 통해 억제한 결과 근섬유의 hypertrophy를 유도하여 어체 무게 증가를 확인한 보고가 있고 [13], myostatin prodomain의 과발현을 통한 유전자조작 제프 라피쉬에서는 무게 변이는 나타나지 않았지만 근 조직 분석을 통해 hyperplasia가 일어났음을 확인하였다[36]. 일반적으로 $20 \mathrm{\mu m}^{2}$ 이하의 근섬유는 hyperplasia를 통해 최근에 생성된 근섬유라고 알려져 있으며[6,32] 어류의 경우 근섬유의 hyperplastic growth가 중단된 이후 장기간에 걸쳐 hypertrophic growth가 일어나는 것으로 알려져 있다[12].

본 연구에서는 어류 유래 재조합 myostatin prodomain 단 백질이 시마연어 성장에서 무게 및 단백질과 지질 함량은 대 
조구와 유사하였지만 조직분석 결과에서 myostatin prodomain이 시마연어의 근육성장에 영향을 미치는 것을 뚜렷이 알 수 있었다(Table 1, Fig. 2). 조직분석에서 근섬유는 12주에 서 22주에 걸쳐 지속적인 hyperplasia를 통해 $20 \mathrm{um}^{2}$ 크기의 새로운 근섬유를 생성하는 것을 확인하였다. 또한 순차적으로 hypertrophy도 유도되었지만, 대조군에 비해 처리한 시마연 어의 무게 증가는 확연한 차이를 보이지 않은 것으로 나타났 다(Fig. 3). 결론적으로 어류 유래 myostatin prodomain이 근 육성장에 중요한 기능을 하는 myostatin의 활성을 조절함으로 써 근섬유의 hypertrophy 및 hyperplasia를 유도한 것으로 사 료된다.

\section{감사의 글}

이 논문은 2010년도 정부(교육과학기술부)의 재원으로 한 국연구재단의 기초연구사업(2010-0023056) 및 국립수산과학 원(RP-2011-BT-009)에 지원에 의하여 연구되었습니다.

\section{References}

1. Acosta, J., Y. Carpio, I. Borroto, O. González, and M. P. Estrada. 2005. Myostatin gene silenced by RNAi show a zebrafish giant phenotype. J. Biotech 119, 324-331.

2. Amali, A. A., C. J. Lin, Y. H. Chen, W. L. Wang, H. Y. Gong, C. Y. Lee, Y. L. Ko, J. K. Lu, G. M. Her, T. T. Chen, and J. L. Wu. 2004. Up-regulation of muscle-specific transcription factors during embryonic somitogenesis of zebrafish (Danio rerio) by knock-down of myostatin-1. Dev. Dyn. 229, 847-856.

3. AOAC. 2005. Official Method of Analysis of AOAC International, 18th eds.

4. Duncan, D. B. 1955. Multiple Range and Multiple F Tests. Biometrics 11, 1-42.

5. Dominique, J. E. and C. Gerard. 2006. Myostatin regulation of muscle development: molecular basis, natural mutations, physiopathological aspects, Exp. Cell Res. 312, 2401-2414.

6. Ennion, S., L. Gauvry, P. Butterworth, and G. Goldspink. 1995. Small-diameter white myotomal muscle fibres associated with growth hyperplasia in the carp (Cyprinus carpid) express a distinct myosin heavy chain gene. J. Exp. Biol. 198, 1603-1611.

7. Gonzalez-Cadavid, N. F., W. E. Taylor, K. Yarasheski, I. Sinha-Hikim, K. Ma, S. Ezzat, R. Q. Shen, R. Lalani, S. Asa, M. Mamita, G. Nair, S. Arver, and S. Bhasin. 1998. Organization of the human myostatin gene and expression in healthy men and HIV-infected men with muscle wasting. Proc. Natl. Acad Sci. USA 95, 14938-14943.

8. Grobet, L., L. J. Martin, D. Poncelet, D. Pirottin, B. Brouwers, J. Riquet, A. Schoeberlein, S. Dunner, F. Menissier, J. Massabanda, R. Fries, R. Hanset, and M. Georges. 1997. A deletion in the bovine myostatin gene causes the dou- ble-muscled phenotype in cattle. Nat. Genet. 17, 71-74.

9. Hill, J. J., M. V. Davies, A. A. Pearson, J. H. Wang, R. M. Hewick, N. M. Wolfman, and Y. C. Qiu. 2002. The myostatin propeptide and the follistatin-related gene are inhibitory binding proteins of myostatin in normal serum. J. Bid. Chem 277, 40735-40741.

10. Hill, J. J., Y. Qiu, R. M. Hewick, and N. M. Wolfman. 2003. Regulation of myostatin in vivo by growth and differentiation factor-associated serum protein-1: a novel protein with protease inhibitor and follistatin domains. Mol. Endocrinol. 17, 1144-1154.

11. Kambadur, R., M. Sharma, T. P. Smith, and J. J. Bass. 1997. Mutations in myostatin (GDF 8) in double-muscled Belgian blue and Piedmontese cattle. Genome Res. 7, 910-916.

12. Kiessling, A., K. Ruohonen, and M. Bjørnevik. 2006. Muscle fiber growth and quality in fish. Arch Tierz Dummerstorf 49, 137-146.

13. Lee, C. Y., S. Y. Hu, and H. Y. Gong. 2009. Suppression of myostatin with vector-based RNA interference causes a double-muscle effect in transgenic zebrafish. Biochem Biophys. Res. Commun. 387, 766-771.

14. Lin, J., H. B. Arnold, and M. A. Della-Fera. 2002. Myostatin knockout in mice increase myogenesis and decreases adipogenesis. Biochem Biophys. Res. Commun. 291, 701-706.

15. Lee, S. B., Y. S. Kim, M. Y. Oh, I. H. Jeong, K. B. Seong, and H. J. Jin 2010. Improving rainbow trout (Oncorhynchus mykiss) growth by treatment with a fish (Paralichthys olivaceus) myostatin prodomain expressed in soluble forms in E. coli. Aquaculture 302, 270-278.

16. Lee, S. J. and A. C. McPherron. 2001. Regulation of myostatin activity and muscle growth, Proc. Natl. Acad Sci. USA 98, 9306-9311.

17. Martin, C. I. and I. A. Johnston. 2005. The role of myostatin and the calcineurin-signalling pathway in regulating muscle mass in response to exercise training in the rainbow trout Oncorhynchus mykiss Walbaum. J. Exp. Biol. 208, 2083-2090.

18. McPherron, A. C., A. M. Lawler, and S. J. Lee. 1997. Regulation of skeletal muscle mass in mice by a new TGF- $\beta$ superfamily member. Nature 387, 83-90.

19. McPherron, A. C. and S. J. Lee. 1997. Double muscling in cattle due to mutations in the myostatin gene. Proc. Natl. Acad Sci. USA 94, 12457-12461.

20. McPherron, A. C. and S. J. Lee. 2002. Suppression of body fat accumulation in myostatin deficient mice. J. Clin. Invest. 109, 595-601.

21. Morrison, B. M., J. L. Lachey, L. C. Warsing, B. L. Ting, A. E. Pullen, and K. W. Underwood. 2009. A soluble activin type IIB receptor improves function in a mouse model of amyotrophic lateral sclerosis. Exp. Neurol. 217, 258-268.

22. Nakamura, T., K. Takio, Y. Eto, H. Shibai, K. Titani, and H. Sugino. 1990. Activin-binding protein from rat ovary I follistatin. Science 247, 836-838.

23. Nicholas, G., M. Thomas, B. Langley, W. Somers, K. Patel, C.F. Kemp, M. Sharma, and R. Kambadur. 2002. Titin-cap associates with, and regulates secretion of myostatin. J. Cell Physiol. 193, 120-131. 
24. Ostbye, T. K., T. F. Galloway, C. Nielsen, I. Gabestad, T. Bardal, and O. Andersen. 2001. The two myostatin genes of Atlantic salmon (Salmo salar) are expressed in a variety of tissues. Eur. J. Biochem 268, 5249-5257.

25. Ostbye, T. K., T. Bardal, A. Vegusdal, O. T. Frang, E. Kjorsvik, and O. Andersen. 2007. Molecular cloning of the Atlantic salmon activin receptor IIB cDNA localization of the receptor and myostatin in vivo and in vitro in muscle cells. Comp. Biochem. Physiol. Part D 2, 101-111.

26. Patruno, M., S. Sivieri, and C. Poltronieri. 2008. Real-time polymerase chain reaction, in situ hybridization and immunohistochemical localization of insulin-like growth factor-I and myostatin during development of Dicentrarchus labrax (Pisces : Ostei-chthyes). Cell Tissue Res. 331, 643-658.

27. Rescan, P. Y., I. Jutel, and C. Ralliere. 2001. Two myostatin genes are differentially expressed in myotomal muscles of the trout (Oncorhynchus mykiss). J. Exp. Biol. 204, 3523-3529.

28. Rescan, P. Y. 2008. New insights into skeletal muscle development and growth in teleost fishes. J. Exp. Zoology (Mol. Dev. Evol.). 310B, 541-548.

29. Robert, S. B. and F. W. Goetz. 2001. Differential skeletal muscle expression of myostatin across teleost species, and the isolation of multiple myostatin isoforms. FEBS Lett. 491, 212-216.

30. Robert, S. B. and F. W. Goetz. 2003. Myostatin protein and RNA transcript levels in adult and developing brook trout. Mol. Cell Endocrinol. 210, 9-20.

31. Sawatari, E., R. Seki, T. Adachi, H. Hashimoto, S. Uji, and
Y. Wakamatsu. 2010. Overexpression of the dominant-negative form of myostatin results in doubling of muscle-fiber number in transgenic medaka (Oryzias latipes). Comp. Biochem Physiol. Part A. 155, 183-189.

32. Stickland, N. C. 1983. Growth and development of muscle fibers in the rainbow trout (Salmo gairdneri). J. Anat. 137, 323-333.

33. Tomas, M., B. Langley, C. Berry, M. Sharma, S. Kirt, J. Bass, and R. Kambadur. 2000. Myostatin, a Negative Regulator of Muscle Growth, Functions by Inhibiting Myoblast Proliferation. J. Biol. Chem 275, 40235-40243.

34. Thomson, A. W., H. R. Turnquist, and G. Raimondi. 2009. Immunoregulatory functions of mTOR inhibition. Nat. Rev. Immunol. 9, 324-337.

35. Wang, H. X., Q. Zhang, and D. H. Zhu. 2003. hSGT interacts with the N-terminal region of myostatin. Biochem Biophys. Res. Commun. 311, 877-883.

36. Xu, C., G. Wu, Y. Zohar, and S. J. Du. 2003. Analysis of myostatin gene structure, expression and function in zebrafish. J. Exp. Biol. 206, 4067-4079.

37. Yang, J., T. Ratovitski, J. P. Brady, M. B. Solomon, K. D. Wells, and R. J. Wall. 2001. Expression of myostatin pro-domain results in muscular transgenic mice. Mol. Reprod DeV. 60, 51-61.

38. Zhang, P., X. Chen, and M. Fan. 2007. Signaling mechanisms involved in disuse muscle atrophy. Med. Hypotheses 69, 310-321.

\title{
초록 : 어류 유래 마이오스타틴 프로도메인 단백질에 의한 시마연어(Oncorhychus masou) 성장효과
}

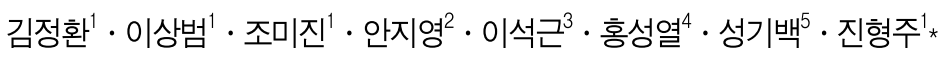 \\ ( ${ }^{1}$ 강릉원주대학교 해양분자생명공학과, ${ }^{2}$ 강릉원주대학교 해양바이오협동과정 해양응용생명공학, ${ }^{3}$ 강릉원주 \\ 대학교 치과대학 구강병리학교실, ${ }^{4}$ 경기도민물고기연구소, ${ }^{5}$ 국립수산과학원 내수면양식연구센터)
}

성장과 분화를 조절하는 인자인 myostatin은 포유류에서 주로 골격근에 분포하며 근육성장을 억제하는 것으 로 알려져 있다. Myostatin은 포유류에서뿐만 아니라 어류에 있어서도 그 기능이 유사하며 본 연구에서는 넙치와 조피볼락 유래 재조합 myostatin 단백 질을 생산하여 시마연어에 침지방법을 통해 처리하였다. 처리 결과 시마연 어의 무게와 생화학 분석에서는 유의성이 나타날 정도의 증가는 없었지만 근(muscle) 조직학적 분석에서 넙치와 조피볼락 유래 재조합 myostatin prodomain에 의해 12 주째에는 세포의 수가 증가하는 hyperplasia가 일어났으며 22주째에는 조피볼락 유래의 재조합 myostatin prodomain을 처리한 군에서만 hypertrophy가 일어났다. 결론적 으로 어류 유래 재조합 myostatin prodomain이 시마연어 근육성장 시 hyperplasia와 hypertrophy가 순차적으로 유도되는 것으로 확인되었다. 